\title{
Kaynaştırma Öğrencilerinin Sosyal Becerilerinin Değerlendirilmesi
}

Bülbin Sucuoğlu*

\author{
Ankara Üniversitesi
}

\author{
Osman Özokçu**
}

\section{Özet}

Bu çalışmanın amacı, ilkokul sınıflarına devam eden kaynaştırma öğrencilerinin sosyal becerilerini, akranlarıyla karşılaştırarak incelemektir. Çalışma grubu, ilköğretim birinci kademe, birinci, ikinci ve üçüncü sınıfa devam eden 613 öğrenciden oluşmuştur. Bu öğrencilerden 53'ü, kaynaştırma öğrencisi olarak tanımlanmıştır. Öğrencilerin sosyal becerileri, sosyal beceri dereceleme ölçeği (SBDS) kullanllarak değerlendirilmiştir. Öncelikle SBDS nin Türkçe formunun geçerlik ve güvenirlik çalışmaları yapılmış, daha sonra kaynaştırma öğrencileri ile diğer öğrencilerin sosyal becerileri ANOVA ile karşılaştırılmış, ayrıca cinsiyet ve sınıf düzeyinin sosyal beceriler üzerinde etkili olup olmadığı tüm çalışma grubu ve kaynaştırma öğrencileri için ayrı ayrı incelenmiştir. Araştırma bulguları, kaynaştırma öğrencilerinin sosyal becerileri ile akademik yeterliliklerinin akranlarından az, problem davranışlarının ise akranlarından fazla olduğunu göstermiştir. Araştırma bulguları SBDS nin özellikleri ve kaynaştırma öğrencilerinin sosyal beceri öğretimi gereksinimleri temel alınarak tartışılmıştır.

Anahtar Sözcükler: Sosyal beceriler, kaynaştırma, engelli öğrenciler.

\section{Abstract}

The purpose of this study was to evaluate the social skills of the mainstreamed elementary students by comparing them with their classmates. The study group consisted of 53 mainstreamed and 560 other elementary

\footnotetext{
Prof. Dr., Ankara Üniversitesi, Eğitim Bilimleri Fakültesi, Özel Eğitim Bölümü, Ankara. E-posta: sucuoğlueankara.edu.tr

** Arş. Gör., Ankara Üniversitesi, Eğitim Bilimleri Fakültesi, Özel Eğitim Bölümü, Ankara. E-posta: osman_ozokcu@hotmail.com
} 
school children ranging from first to third grades. The Social Skills Rating System (SSRS), Teacher Form, grades K-6 which requires the teachers to rate each student on a 3 point Likert-type scale was used to evaluate the social skills of the group. First, reliability and validity studies were conducted for the Turkish Form of the SSRS and then the social skills of the two group were compared by using a one way analysis of variance. Moreover, gender and grade level variables were investigated in terms of their effectiveness on social skills. The results of the analysis revealed that the social skills and the academic competencies of the maintreamed students were fewer, and problem behaviors were more than their classmates. The results were discussed in terms of the characteristics of the SSRS and the social skill training needs of the mainstreamed group.

Key Words: Social skills, mainstreaming, children with disabilities.

Engelli çocukların, eğitimlerini destek özel eğitim hizmetleri alması koşulu ile genel eğitim okullarında akranlarıyla birlikte sürdürmeleri olarak kabul edilen kaynaştırma yaklaşımı, son otuz yıldır yaygin olarak benimsenmekte, bunun sonucu olarak da bir çok ülkede engelli öğrenciler engelli olmayan akranları ile birlikte, genel eğitim okullarında eğitim görmektedirler. Birlikte eğitimin amacı, engelli öğrencilerin akranlarıyla akademik ve sosyal yönden bütünleştirilerek sosyal ve duygusal gereksinimlerinin karşılanmasıdır. kaynaştırma engelli gelişimleri çocukları lamalarin Ancal mleri ve sosyal becerileri üzerindeki etkileri konusunda çelişkili çalışma sonuçları bulunmaktadır. Bazı çalışmalarda, heterojen sınıflarda engelli olan ve olmayan çocukların birbirleriyle doğal olarak etkileşime girecekleri, bu nedenle engelli öğrencilerin hem akademik hem de sosyal becerilerinin artacă̆ı savunulmaktadır (Ciechalski ve Schmidt, 1995). Bu bakış açısıyla, kaynaştırma uygulamaları sonucunda tüm öğrencilerin bireysel farklılıkları anlayarak, bu farklılıklara sayg göstermeyi öğrenecekleri, iletişim, arkadaşlık ve birlikte çalışma becerilerinin artacağı (Madden ve Slavin, 1983) ve engelli öğrencilerin sosyal becerilerinin gelişeceği kabul edilmektedir (Hunt, Atwell, Farron-Davis ve Goetz, 1996; Vaughn, Elbaum ve Schumm, 1996). Gresham (1983) ise durumu farklı yönden değerlendirmekte, çocuğun nereye / hangi eğitim kurumuna yerleştirileceğine karar vermede akademik ve zihinsel işlevlerinin yanı sıra engelli öğrencilerin sosyal becerilerdeki düzeyinin de yerleştirmenin etkileyen önemli bir faktör olduğunu belirtmektedir. Buna göre, engelli öğrencilere, genel eğitim sınıflarına yerleştirilmeden önce, temel sosyal becerilerin öğretilmemesi, bu öğrencilerin kaynaştrma ortamlarındaki başarılarını olumsuz yönde etkileyecektir (Maag ve Webber, 1995).

Engelli çocukların sosyal becerileri engelli olmayan akranlarına göre sınırlıdır ve bu sinirlılık hem akranlar hem de yetişkinlerle etkileşim kurmada çeşitli problemlere yol açmaktadır (Sabornie ve Beard, 1990). Bu çocuklar, akranları ile sosyal 
etkileşime girmek için daha az girişimde bulunmakta akranlarının etkileşim çabalarına onların anlamadığı şekilde tepkiler verebilmektedirler (Beckman ve Kohl, 1987; Guralnick ve Groom, 1987). Ayrıca iletişim becerilerinin sınırlı olması da, sosyal etkileşimlerini azaltmaktadır (Guralnick, 1990). Diğerlerinin duygularını anlayamama (O'Neill, 1997), uygun zamanda ve yerde duygularını gösterememe (Hubbard ve Coie, 1994) ve akranları tarafindan kabul edilmeyen gruba girme becerileri (Siperstein ve Leffert, 1997), sosyal etkileşimlerini olumsuz etkilemektedir (Akt., Snell ve Janney, 2000). Engelli öğrencilerin genellikle az arkadaşları vardır ve kaynaştırma ortamlarında engelli olmayan akranlarına göre daha düşük sosyal statüye sahiptirler (Akt., Ciechalski, 1995). Bu çocukların sosyal becerilerinin yetersiz olması ve / veya öğrendikleri sosyal becerileri uygun olarak kullanamamaları, karşılaştıkları çeşitli sosyal problemlerin nedeni olarak kabul edilmektedir (Gresham, 1986). Çünkü, sosyal beceriler bireyin akranları, öğretmenleri, ailesi ve diğerleriyle olumlu sosyal ilişkiler kurması, bu ilişkileri sürdürmesi için gereklidir (Kolb, Hanley ve Maxwell, 2003) ve bu beceriler akran kabulü ile sosyal uyumu kolaylaştırır, çevrenin sosyal beklentileri ile baş etmeyi sağlar (Akt., Gresham, Sugai ve Horner, 2001).

Sosyal beceri yetersizlikleri, akademik becerilerde başarısızlığa yol açmakta; akademik başarı ile sosyal becerilerin yakından ilişkili olduğu belirtilmektedir
(Chadsey-Rusch, 1992; Sargent, 1991; Zirpoli ve Melloy, 1997). Sosyal statü farklı ortamlardaki başarıyı etkilemekte, sosyal kabul ise çocuğun grupta akranları ile çalışması ve gerektiği durumlarda akranlarından yardım alabilmesi ile ilişkili görülmektedir. Akademik ortamlarda akranları tarafindan kabul edilmeyen çocuklar genelikikle okulu sevmemekte ve kabul gören akranları kadar başarılı deneyimler yaşamamaktadırlar (Snell ve Janney, 2000). Bu nedenlerle engelli öğrencilerin akranlarından gerekli desteği alabilecekleri sosyal çevreyi oluşturabilmeleri için sosyal beceri öğretimi gerekli görülmektedir.

öğrencilerin sergiledikleri problem davranişlar sosyal beceri yetersizlikleri ile ilişkilidir ve çocukluk döneminde sosyal problemler yaşayan hem engelli hem de engelli olmayan bireylerin, yetişkinlik içselleştirilmiş dışsallaştırılmış yaşama riskleri daha fazladır (Clegg ve Standen, 1991). Sosyal becerileri öğrenmemiş ya da öğrenmiş olan ancak kullanamayan öğrencilerin, sosyal beceriler yerine, isteklerini elde etmek için çeşitli problem davranışlar sergileyebileceği kabul edilmektedir. Akranlarının elindekini kapma, itme gibi problem davranışlar, "oyuncağı almak" ya da "sırada yer kapmak" gibi isteklerine ulaşmayı kolaylaştırdığı için, bu çocuklara izin almak, sormak ya da beklemek gibi sosyal becerileri kullanmaktan daha kolay gelebilir (Gresham, 1997). 
İlköğretim okullarında eğitimin odak noktasi akademik becerilerdir ve temel amaç öğrencilere akademik beceriler

dolayısıyla

programlarında

kazandırmaktır, müfredat akademik beceriler dışında kalan becerilere yeterince yer verilmemektedir. Oysa, sosyal beceriler, daha geniş bir yapı olan sosyal yeterliliğin bir parçasıdır ve öğrencinin okulda başarılı olabilmesi için akademik yeterlilik kadar sosyal yeterliliğinin de olmasi gerekmektedir (Gresham, 1986). Kaynaştırma uygulamalarına devam eden engelli öğrencilerin akademik becerileri öğrenmelerini kolaylaştırmak, problem davranışlarını önlemek, azaltmak, sosyal kabulü, akranlar ve yetişkinlerle etkileşimi arttırabilmek amacıyla sosyal beceri programlari geliştirilmektedir. Bu programlarin etkili olabilmesi için öncelikle çocukların gereksinimlerini, yetersizliklerini temel almasi (Gresham ve diğ., 2001); öğretim programı öncesinde farklı değerlendirme yöntemleri kullanılarak öğrencilerin sosyal yetersizliklerinin ve hangi sosyal becerilerin öğrenci için en önemli olduğunun (Miller, Lane ve Wehby, 2005; Snell ve Janney, 2000) belirlenmesi gereklidir.

Sosyal beceriler sosyometrik yöntemler, doğal ortamlarda yapılan davranışsal gözlemler ve dereceleme ölçekleri gibi farklı teknikler kullanılarak değerlendirilmekte, anne baba, öğretmen, akran ya da çocuğun kendisi tarafından doldurulan davranış dereceleme ölçekleri, yaygın kullanılan araçlar arasında yer almaktadır (Sargent, 1991; Zirpoli ve Melloy, 1997). Sosyal beceri dereceleme sistemi (SBDS) (Gresham ve Elliot, 1990), okul öncesi dönemden 12. sınıfa kadar olan okul çocuklarının sosyal becerilerini değerlendirmek amacıyla geliştirilmiş ve yaygın olarak kullanılan bir davranış dereceleme ölçeğidir. Anne baba, öğretmen ve öğrenci formu olan bu ölçek, pek çok araştırmada veri toplamak amacıyla kullanılmıştır. Dereceleme sistemi ile öğrencilerin sosyal becerileri ayrintilı olarak değerlendirilmekte, bu becerilerin öğrenimi ve kullanımını etkileyen problem davranişlar da ölçülmektedir. SBDS ile sosyal beceri yetersizlikleri ve bu yetersizliklere paralel olarak ortaya çıkan akademik yetersizlikler de değerlendirilmekte, bunun yanı sira sosyal beceriler, akademik başarı ve problem davranışlar arasındaki ilişkiye ilişkin de bilgi edinilmektedir (Gresham ve Elliot, 1990). Bu bilgi, özellikle öğretmenler için çok önemli bir bilgidir çünkü, sosyal becerilerin genellikle öğrencinin akademik becerileri ve problem davranışları ile ilgili olduğu düşünülmekte, dolayısıyla sosyal beceri öğretimi ile hem akademik beceriler arttırılmakta hem de problem davranısları azaltmaktadır (Merrell ve Gimpel, 1998). Araştırmacılar SBDS kullanılarak öğrencilerin sosyal becerilerine ilişkin bilgi toplamanın yanı sira, SBDS ile öğretmenlerin öğrencilerin sınıf başarısı için hangi sosyal becerileri önemli gördükleri konusunda bilgi edinebilmektedirler. Öğretmenler sosyal beceri alt ölçeğini kullanarak; ölçekte yer alan 30 
sosyal beceriyi, sınıf başarısı üzerindeki önem derecesine göre derecelendirmektedirler. Böylece her öğretmenin, sınıfındaki öğrenciler için hangi sosyal becerileri önemli gördüğü belirlenerek, sosyal beceri öğretim programlarında bu becerilere özellikle yer verilmektedir. Aracın önemli bir özelliği, SBDS ile belirlenen sosyal beceri yetersizliklerine odaklanan programlar hazırlanabilmesi ve uygulanan bu programların etkililiğinin değerlendirilebilmesidir. Miller ve diğerleri (2005), davranıs problemleri olan engelli çocukların sosyal beceri yetersizliklerini ve bu yetersizlikleri içeren okul tabanlı bir sosyal beceri öğretim programinin etkisini SBDS ile belirlemişler, Silver, Elder ve DeBolt (1999) ise, SBDS'nin öğretmen formunu kullanarak matematik alanında öğrenme güçlüğü olan öğrencilerin sosyal becerilerini değerlendirmişlerdir. öğretmenlerin okul başarısı için hangi sosyal becerileri önemli gördüklerini araştıran Lane (2004 a, b), hem ilkokul hem de ortaokul öğretmenlerinin kritik gördükleri sosyal becerileri belirlemiş ve bu becerilerin sosyal beceri öğretimi programlarında yer almasını önermiştir.

Ülkemizde,

uygulamalari ve bu ilişkin sorunları inceleyen çalışmalar bulunmakla birlikte, kaynaştırma uygulamalarına devam eden özel gereksinimli öğrencilerin sosyal becerileri, sosyal statü ve sosyal kabullerinin, çok az sayıda çalışmada incelendiği görülmektedir. Akçamete ve Ceber
(1999), lise düzeyinde kaynaştırma uygulamalarına devam eden işitme engelli olan ve olmayan öğrencilerin sosyal statülerini arasında fark bulamamışlar ve bu bulguyu işitme engelli öğrencilerin akranları tarafından kabul edildikleri şeklinde yorumlamışlardır. Kaynaştırma sınıflarına devam eden zihin engelli öğrencilerin sosyal kabul düzeylerini araştıran benzer bir çalışmada ise zihinsel engelli öğrencilerin sosyal kabullerinin akranlarından düşük olduğu, akranları tarafından daha az kabul edildikleri bulunmuştur (Şahbaz, 2004). Kaynaştırma uygulamaları ve özel eğitim okuluna devam eden işitme engelli küçük çocukların sosyal becerileri ile problem davranışları, engelli olmayan akranları ile karşılaştırıldığı zaman, iki grup küçük çocuğun sosyal etkileşimleri ve sosyal işbirlikleri arasında anlamlı fark bulunamamıştır (Poyraz-Tüy, 1999). Zihinsel engelli çocukların sosyal becerilerini araştıran iki çalışmaya ulaşılmıştır. Birinci çalışmada, okul öncesi dönemindeki Down sendromlu ve normal gelişim gösteren çocukların kaynaştırma ortamındaki sosyal iletişim davranışları incelenmiş (Baysal, 1989), diğerinde ise, ana sınıfına yerleştirilen zihinsel engelli öğrencilerin sosyal becerilerini engelli olmayan akranlarının sosyal becerileri ile karşılaştırılmıştır (Uysal, 1999). Her iki çalışmada da zihinsel engelli öğrencilerin sosyal becerilerinin akranlarından daha az olduğu bulunmuştur.

Kaynaştırma uygulamalarına devam eden engelli öğrencilerin sosyal beceri yetersizlikleri ve gereksinimlerinin belirlenmesi ile 
bu becerilere programlarının kolaylaşacak, öğretmenlerinin odaklanan öğretim hazırlanması sinlf akademik yetersizlikler yanı sira sosyal beceriler üzerinde çalışarak öğrencilerin sosyal uyumu, sosyal kabulleri ve akademik becerilerinin gelişmesine katkıda bulunmaları sağlanabilecektir. Bu nedenle bu çalışmada a. ilköğretim okullarına devam eden özel gereksinimli öğrencilerin sosyal becerilerini akranları ile karşılaştırmak, b. sosyal beceri puanlarının, öğrencilerin cinsiyet ve sınıf düzeyine göre değişip değişmediğini amaçlanmıştır.

\section{Yöntem}

Bu araştırma, kaynaştırma sınıflarına devam eden engelii ve engelli olmayan öğrencilerin sosyal becerilerini karşılaştırmalı olarak inceleyen betimsel bir çalışmadır.

\section{Çalışma Grubu}

$\mathrm{Bu}$ araştırmanın çalışma grubu, Ankara ilinde kaynaştırma uygulamaları yürütülen iki ilköğretim okulunun 1.-3. sınıf öğrencilerinden oluşan toplam 613 öğrencidir. Araştırmada, Rehberlik Araştırma Merkezi tarafından "öğrenme zorluğu, yavaş öğrenen" olarak belirlenen çocuklar ile herhangi bir tanısı olmayan ancak öğretmenleri tarafından öğrenme zorlukları olduğu belirtilen ve akademik başarıları sürekli / tutarlı olarak sınıfın altında olan 53 çocuk kaynaştırma öğrencisi (KÖ) Olarak tanımlanmıştır. Böylece 53 kaynaştırma öğrencisi ve 560 engelli olmayan öğrenci sosyal becerileri, problem davranışları ve akademik yeterlilikleri açısından değerlendirilmişlerdir. Araştırma grubuna alınan okullar, sınıflar ve öğrenci sayıları Tablo $1^{\prime}$ de verilmiştir.

Tablo 1

Araştırma Grubunun Okul, Sınıf ve Öğrenci Sayılarına Göre Dă̆ılımı

\begin{tabular}{|c|c|c|c|c|c|c|}
\hline \multirow[t]{2}{*}{ Okul } & \multirow{2}{*}{$\begin{array}{c}\text { Sin } \\
\text { If }\end{array}$} & \multicolumn{2}{|c|}{ Cinsiyet } & \multirow{2}{*}{$\begin{array}{l}\text { Kaynaştır } \\
\text { ma } \\
\text { Öğrencisi }\end{array}$} & \multirow[t]{2}{*}{ Diğer } & \multirow[t]{2}{*}{ Toplam } \\
\hline & & Kız & Erkek & & & \\
\hline A OKULU & 13 & 220 & 213 & 33 & 400 & 433 \\
\hline B OKULU & 20 & 62 & 118 & 20 & 160 & 180 \\
\hline Toplam & 33 & 282 & 331 & 53 & 560 & 613 \\
\hline
\end{tabular}

\section{Veri Toplama Araçları}

$\mathrm{Bu}$ çalışmada veri toplamak amacıyla Gresham ve Elliot (1990) tarafından geliştirilen Sosyal Beceri Derecelendirme Sistemi-SBDS (Social Skills Rating System) kullanılmıştır. SBDS, okul öncesi ve ilköğretim öğrencilerinin sosyal becerileri ve bu becerilerle ilişkili olduğu kabul edilen davranış problemleri ile akademik yeterliliklerini belirlemek amacıyla geliştirilmiştir. Engelli olan ilköğretim okulu çocukları için de normları çıkarılmış olan SBDS ile sosyal beceri yetersizlikleri belirlenerek sosyal beceri eğitim programların hazırlanacağı ve 
eğitim programlarının etkisinin değerlendirilebileceği

belirtilmiştir (Gresham ve Elliot, 1990). Bu çalışmada SBDS'nin, anasınıfı - 6. sınıf çocuklarını değerlendirmek için geliştirilen öğretmen formu kullanılmıştır, çünkü, öğretmenler öğrencileri doğal ortamlarında, farklı etkinlikler ve dersler surasinda gözlemleme şansına sahiptirler. Benzer yaşlarda ve farklı özellikleri olan çocuklarla etkileşimde bulunmak, öğretmenlerin çocukların davranışlarına ilişkin standartlar oluşturmalarını kolaylaştırır. Genellikle öğretmenler, öğrencilerin davranışları hakkında güvenilir ve anlamlı bilgi verebilmektedirler. Bu nedenle öğretmenlerin dereceleme ölçekleri kullanılarak yaptıkları değerlendirme sonucunda, sosyal beceriler ve sosyal beceri yetersizliklerine ilişkin geçerli ve güvenilir bilgi edinildiği kabul edilmektedir (Margetts, $2000)$.

Sosyal beceri dereceleme sistemi'nde üç ayrı ölçek bulunmaktadır (Gresham ve Elliot, 1990) :

\section{Sosyal Beceri Ölçeği} (SBÖ/Social Skills): SBÖ'nde, işbirliği, atılganlık ve kendini kontrol ölçekleri olmak üzere üç alt ölçek yer almaktadır. İşbirliği ölçeği, diğerlerine yardım etme, eşyalarını paylaşma, kurallara ve yönergelere uyma vb. davranışları; atılganlık ölçeği, bilgi isteme, kendini tanıtma ve diğerlerine tepki verme gibi etkileşim başlatma davranışlarını; kendini kontrol ölçeği ise, öfke kontrolü, anlaşmazlık durumunda uzlaşma sağlama ve uygun şekilde tepki verme gibi anlaşmazlık durumunda sergilenecek davranışları kapsamaktadır. SBÖ, her öğrencinin son bir ay ya da son iki ay boyunca sergilediği davranışları düşünülerek, ölçekte yer alan her davranışı öğrencinin hangi sıklıkta yaptığına karar verilmesi ile doldurulmaktadır. Eğer öğrenci bir davranışı, asla/hiç yapmıyorsa sıfır (0), bazen yapıyorsa bir (1), çok sık yapıyorsa iki (2) işaretlenmektedir. SBÖ' nden elde edilecek toplam puan 0 ile 60 puan arasında değişmektedir. Sosyal beceri ölçeği ile her davranışın sıklığının değerlendirilmesinin yanı sıra, öğretmen, ölçekteki her sosyal davranışı, sınıftaki başarı için önemi açısından da değerlendirilmektedir. Bir davranışın sınıf başarısında ne kadar önemli olduğunu belirlemek için, o davranış sınıf başarısı için önemli değilse sıfır (0), önemli ise bir (1), kritik ise iki (2) olarak derecelendirilmektedir.

2. Problem Davranış Alt Ölçeği (PDÖ/Problem Behaviors): Bu alt ölçek davranışlar, dışsallaştırılmış içselleştirilmiş davranişlar ve hiperaktivite alt ölçeklerinden oluşmaktadır.

Dışsallaştırılmış davranışlar alt ölçeğinde, tartışma, düşük öfke kontrolü ve diğerlerine karşı sözel ve fiziksel şiddetle ilgili uygun olmayan davranişlar yer alırken,

içselleştirilmiş davranışlar alt ölçeği, düşük benlik saygısı, yalnızlık, kaygı gibi davranışlardan oluşmaktadır. Aşırı hareketlilik ölçeği ise, aşırı hareketlilik ve yerinde duramama ve dikkat dağınıklığı gibi davranışları içermektedir. Öğrencinin problem davranışları sosyal beceri ölçeğine benzer şekilde değerlendirilmekte, 
öğrenci bir problem davranışı, asla/hiç yapmıyorsa sıfır (0), bazen yapıyorsa bir (1), çok sık yapıyorsa iki (2) işaretlenmektedir. PDÖ'nden elde edilecek toplam puan 0 ile 36 arasında değişmektedir.

\section{Akademik Yeterlilik ölçeği} (AYÖ/Academic Competence) : $\mathrm{Bu}$ ölçek okuma-yazma ve matematik becerileri, motivasyon, aile desteği ve genel bilişsel işlevleri değerlendiren maddelerden oluşan bir ölçektir. ölçeğin öğretmen formunda bulunan bu alt ölçek maddeleri, öğrenme güçlüğü olan çocukların sosyal becerilerine ilişkin ilginin artmasi ve hafif derecede engelli olan çocukların sosyal beceri yetersizlikleri olduğunu gösteren araştırma bulgularının olması nedeniyle SBDS de yer almıştır. Akademik yeterlilik ölçeğinde 9 madde bulunmakta, her madde 1 ile 5 arasında değerlendirilmektedir. (1) rakamı çocuğu $\bigcirc$ madde için sınıfın en alt o10'una yerleştiren en düşük performansı, (2) rakamı çocuğun sonraki en düşük \%20'sine yerleştiren düşük performansı, (3) rakamı çocuğun sınıfın orta \%40'ına yerleştiren performansı, (4) rakamı çocuğun sonraki en yüksek 20'sine yerleştirilen performansı ve (5) rakamı ise çocuğu sınıfın en üst o10'una yerleştiren en üst ya da en uygun performansı göstermektedir. AYÖ' nden elde edilecek toplam puan 9 ile 45 arasında değişmektedir (Gresham ve Elliot, 1990). $\mathrm{Bu}$ araştırmacılar İngilizce' den çalışmada, tarafından Türkçe'ye çevrilerek, Türkçe Form için alanda uzman olan ve her iki dile hakim üç hakemin görüşlerine baş vurulmuştur. Hakemlerden gelen çeviriler incelenerek düzeltmeler yapılmış ve Türkçe Form son halini almıştır. Daha sonra ölçeğin Türkçe Formu iki dile de hakim 3 uzman tarafindan tekrar İngilizce'ye çevrilerek özgün ifadelerle karşılaştırılmıştır. İki form arasında fark gösteren maddelerin Türkçe'si yeniden gözden geçirilerek gerekli düzeltmeler yapılmış ve ölçeğin dil açısından son hali elde edilmiştir.

\section{A) Geçerlik Çalışmaları:}

Faktör analizi: Faktör analizi için ilk olarak ölçeğin sosyal beceriler, problem davranişlar ve akademik yeterlilik alt ölçekleri için ayrı ayrı Temel Bileşenler Analizi yapılmış, daha sonra orijinal ölçekte yer alan alt faktörler temel alınarak bir dik döndürme yöntemi olan varimax rotasyonu kullanllarak faktör analizi çalışmaları yürütülmüştür. Aşağıda SBDS'de yer alan üç alt ölçeğin faktör analizi sonuçları ayrı ayrı açıklanmıştır.

a) Sosyal beceriler ölçeği: Faktör analizi sonucunda orijinal ölçekte yer alan işbirliği, atılganlık ve kendini kontrol alt faktörlerinden oluşan 3 faktörlü yapının korunduğu ancak her faktörde yer alan bazı maddelerin diğer faktörlerde yer aldığı, 3 faktörün toplam varyansın 59.75 ini açıkladığı görülmüştür. Özgün ölçekte işbirliği başlığı altında yer alan 10 madde $(9,15,28,29$, 16, 26, 20, 21, 8, 27) Türkçe Formda atılganlık faktöründe yer almış;özgün ölçekte atılganlık başlığı altında yer alan 10 madde ise $(14,2,3,7,17,10,19,6$, 23, 24, ) Türkçe Formda işbirliği faktörüne gitmiştir. Kendini kontrol faktöründe yer alan 10 
maddenin 7'si $(18,4,1,12,13$, 25, 30) Türkçe Formda yine kendini kontrol faktöründe yer almış, kalan 3 maddenin birisi olan 22 . madde, faktör yükü .30 dan düşük olduğu için ölçekten çıkarılmış, 5 ve 11. maddeler ise işbirliği faktöründe yer almıştır. Böylece ölçeğin Türkçe Form'unda, işbirliği faktöründe 12 , atılganlık faktöründe 10 ve kendini kontrol faktöründe 7 madde olmak üzere toplam 29 madde yer almıştır. SBÖ'nin faktör yapısı ve madde toplam korelasyonları Tablo 2'de verilmiştir.

\section{Tablo 2}

SBÖ’nin Türkçe Formunun Faktör Yapısı*

\begin{tabular}{|c|c|c|c|c|}
\hline Maddeler & $\begin{array}{l}\text { Faktör } \\
1\end{array}$ & $\begin{array}{l}\text { Faktör } \\
\quad 2\end{array}$ & $\begin{array}{l}\text { Faktör } \\
3\end{array}$ & $\mathbf{r}$ \\
\hline 1(14)**.Yaşıtlarıyla konuşma başlatır. & .82 & .12 & .12 & .59 \\
\hline 2 (7). Diğerlerini etkinliğe katılmaları için davet eder. & .81 & .26 & .11 & .69 \\
\hline $\begin{array}{c}3 \text { (2). Kendisine söylenmeden kendini yeni bir kişiye } \\
\text { tanıtır. }\end{array}$ & .77 & .15 & - & .58 \\
\hline $\begin{array}{c}4(3) \cdot \text { Haksız olabilecek kuralları uygun sekilde } \\
\text { sorgular. }\end{array}$ & .77 & .32 & - & .67 \\
\hline $\begin{array}{l}5(23) \text { S Sınıf çalışmalarında akranlarına yardım etmede } \\
\text { gönüllü olur. }\end{array}$ & .72 & .26 & - & .67 \\
\hline 6(10). Kolayca arkadaş edinir. & .72 & .34 & - & .58 \\
\hline $\begin{array}{l}7(24) \text { Devam eden bir etkinliğe ya da bir gruba kendisine } \\
\text { söylenmeksizin katılır. }\end{array}$ & .70 & - & .34 & .60 \\
\hline 8(19). Akranlarına iltifat eder. & .69 & .38 & .21 & .55 \\
\hline $\begin{array}{cc}9 & (6) \\
\text { șeyler söyler. }\end{array}$ & .68 & .16 & .35 & 54 \\
\hline $\begin{array}{l}\text { 10(11). Akranlarını alay etmelerine uygun sekilde tepki } \\
\text { verir. }\end{array}$ & .52 & .18 & .27 & .59 \\
\hline 11 (5). Akran baskısına uygun șekilde tepki verir. & .51 & .11 & .36 & .53 \\
\hline $\begin{array}{l}\text { 12(17) . Kendisine haksız şekilde davrandığınızı düşündüğü } \\
\text { zaman bunu uygun șekilde söyler. }\end{array}$ & .34 & .15 & - & .57 \\
\hline 13 (9). Sınıf ödevlerini verilen zaman içinde tamamlar. & .26 & .78 & .13 & .67 \\
\hline 14(28). Dersi dikkatlice dinler/derse dikkat eder. & .26 & .77 & .19 & .69 \\
\hline $\begin{array}{l}\text { 15(27). Çalışma sırasını hatırlatmaksızın temiz ve düzenli } \\
\text { tutar. }\end{array}$ & .29 & .74 & - & .66 \\
\hline 16(15). Yardım beklerken zamanı uygun şekilde kullanır. & .15 & .72 & .31 & .71 \\
\hline 17(16). Okul ödevlerini doğru yapar. & .33 & .72 & .25 & .69 \\
\hline $\begin{array}{l}\text { 18(21). Çalışma materyallerini ya da okul eşyalarını yerine } \\
\text { kaldırır. }\end{array}$ & .40 & .71 & .19 & .55 \\
\hline 19(29). Bir sınıf etkinliğinden diğerine kolayca geçer. & - & 71 & .31 & .76 \\
\hline $20(20)$.Yönergelerinize uyar. & - & 71 & .39 & .59 \\
\hline 21 (8). Boș zamanlarını uygun șekilde kullanır. & .31 & .66 & .18 & .74 \\
\hline $\begin{array}{l}22(26) \text {. Sınıf çalışmalarında akranlarının dikkatini } \\
\text { dağıtmalarına izin vermez. }\end{array}$ & .38 & .53 & .13 & .60 \\
\hline $\begin{array}{l}\text { 23(18) . Grup etkinlikleri için akranlarının fikirlerini } \\
\text { kabul eder. }\end{array}$ & - & .13 & .75 & .39 \\
\hline $\begin{array}{l}24 \text { (4). Anlaşmazlık durumunda kendi fikirlerini } \\
\text { değiştirerek uzlaşma sağlar. }\end{array}$ & - & - & .75 & .45 \\
\hline $\begin{array}{l}25 \text { ( 1). Akranlarıyla anlaşmazlık durumunda öfkesini kontrol } \\
\text { eder. }\end{array}$ & - & .27 & .71 & .45 \\
\hline $\begin{array}{l}26(12) \text {. Yetişkinlerle anlaşmazlık durumunda öfkesini kontrol } \\
\text { eder. }\end{array}$ & .20 & .24 & .68 & .45 \\
\hline 27(13). Eleștiriyi iyi șekilde kabul eder. & .36 & .27 & .67 & .45 \\
\hline $\begin{array}{l}28(25) \text {. Diğer çocuklar ittiği ya da vurduğu zaman, uygun } \\
\text { tepki verir. }\end{array}$ & .11 & .27 & .34 & .48 \\
\hline 29(30). Yabancılarla/farklı kişilerle iyi geçinir. & .36 & .33 & .55 & .66 \\
\hline
\end{tabular}

* Faktör yükleri. 10 dan küçük olan maddelerin faktör yükleri tabloda gösterilmemiştir.

** Orijinal ölçeğin madde numaraları 
b) Problem davranışlar ölçeği: PDÖ'nin faktör analizi için ilk olarak Temel Bileşenler Analizi yapılmış, daha sonra bir dik döndürme yöntemi olan varimax rotasyonu yöntemi, problem davranışlar ölçeğinde yer alan 3 faktöre göre yinelenerek analize devam edilmiştir. Bu ölçek için yapılan faktör analizi sonucunda orijinal ölçekte yer alan dışsallaştırılmış davranışlar, içselleştirilmiş davranışlar ve hiperaktivite alt faktörlerinden oluşan üç faktörlü yapının ölçeğin Türkçe formunda dışsallaştırılmış davranışlar ve içselleştirilmiş davranışlar olmak üzere iki faktörlü yapıya dönüştüğü görülmüştür. Faktör analizi sonucunda iki faktörün toplam varyansın o61.79'unu açıkladığı görülmüştür. Özgün ölçekte dışsallaştırılmış

davranışlar faktöründe yer alan 6 madde (43, 31, 33, 44, 42, 41) ile hiperaktivite faktöründe yer alan 6 madde $(35,48,40,36,47,37)$ Türkçe Formda dışsallaştırılmış davranışlar faktöründe yer almıştır. Özgün ölçekte içselleştirilmiş davranışlar faktöründe yer alan 6 madde ise (34, 46, 38, 32, 39, 45 ) Türkçe Formda

davranışlar faktöründe yer almiştır. Problem davranış ölçeğinin yeni faktör yapısında, dışsallaştırılmış davranışlar faktöründe 12, içselleştirilmiş davranışlar faktöründe 6 madde olmak üzere toplam 18 madde bulunmaktadır. PDÖ'nin faktör yapisı ve madde toplam korelasyonları Tablo 3'de verilmiştir.

Tablo 3

PDÖ'nin Türkçe Formunun Faktör Yapısı*

\begin{tabular}{|c|c|c|c|}
\hline Maddeler & Faktör 1 & Faktör 2 & $\mathbf{r}$ \\
\hline $30(36) * *$. Diğerlerinin sözlerini keser. & .83 & - & .77 \\
\hline 31(37). Devam eden bir etkinliği bozar. & .81 & .15 & .66 \\
\hline Diğerleriyle kavga eder. & .80 & .22 & .74 \\
\hline Diğerleriyle tartışır. & .80 & .37 & .75 \\
\hline Düşüncesizce davranır. & .79 & .14 & .76 \\
\hline $35(33) . \quad$ Diğerlerini tehdit eder. & .79 & .22 & .74 \\
\hline $\begin{array}{l}36(48) \text { Yerinde duramaz ya da aşırı } \\
\text { hareketlidir }\end{array}$ & .79 & .31 & .72 \\
\hline $37(43) . \quad$ Kolay sinirlenir. & .77 & - & .72 \\
\hline Düzeltildiğinde yetişkine karşılık & .70 & - & .65 \\
\hline Öfke nöbetleri vardır. & .66 & - & .62 \\
\hline Kendisine söylenilenleri dinlemez. & .65 & .36 & .63 \\
\hline Üzgün ya da depresif davranır. & .57 & .44 & .59 \\
\hline Yalnız görünür. & .54 & .84 & .74 \\
\hline Yalnız olmayı sever. & - & .83 & .73 \\
\hline $\begin{array}{l}\text { 44(38) . Bir çocuk grubuyla beraber olmaktan } \\
\text { kayg duyar. }\end{array}$ & - & .81 & .47 \\
\hline $45(32)$. Kendisine güveni azdır. & .18 & .79 & .69 \\
\hline Kolayca utanır. & - & .70 & .53 \\
\hline Kolayca dikkati dağılır. & .22 & .57 & .51 \\
\hline
\end{tabular}

* Faktör yükleri. 10 dan küçük olan maddelerin faktör yükleri tabloda gösterilmemiştir. 
** Orijinal ölçeğin madde numaraları

c) Akademik yeterlik ölçeği: AYÖ'nin faktör analizi için diğer ölçeklerde olduğu gibi öncelikle Temel Bileşenler Analizi yapılmış, ve varimax rotasyonu yöntemi ile, akademik yeterlilik ölçeğinde yer alan tek faktöre göre yinelenerek analize devam edilmiştir. Yapılan analiz sonucunda ise, özgün ölçekte akademik yeterlilik faktöründe yer alan 9 maddenin hepsi Türkçe Formda da yer almış, ölçekten atılan madde olmamıştır. Ölçeği oluşturan tek faktör açıklanan toplam varyansın 87.06 sını açıklamaktadır. AYÖ'nin faktörleri ve madde toplam korelasyonları Tablo 4'de verilmiştir.

\section{Tablo 4}

AYÖ’nin Türkçe Formunun Faktör Yapısı *

\begin{tabular}{|c|c|c|}
\hline Maddeler & Faktör 1 & $r$ \\
\hline $\begin{array}{l}48(49) * \star \text {. Sınıfımdaki diğer öğrencilerle } \\
\text { karşılaştırıldığı zaman, bu çocuğun toplam akademik } \\
\text { performansı }\end{array}$ & .97 & .96 \\
\hline $\begin{array}{l}49(50) \cdot \text { Diğer çocuklara göre bu çocuğun okumada } \\
\text { durumu nasıldır? }\end{array}$ & .95 & .91 \\
\hline $\begin{array}{l}50(51) \text {. Diğer çocuklara göre bu çocuğun matematikte } \\
\text { durumu nasıldır? }\end{array}$ & .95 & .94 \\
\hline $\begin{array}{l}51(52) \text { Sınıf düzeyi beklentilerine göre, bu çocuğun } \\
\text { okuma becerileri }\end{array}$ & .95 & .91 \\
\hline $\begin{array}{l}\text { 52(53) . Sınıf düzeyi beklentilerine göre, bu çocuğun } \\
\text { matematik becerileri }\end{array}$ & .95 & .94 \\
\hline $\begin{array}{l}53(54) \cdot \text { Akademik başarı için bu çocuğun genel } \\
\text { motivasyonu }\end{array}$ & .93 & .94 \\
\hline $\begin{array}{ll}\text { 54 (55) } & \text { Akademik başarı için bu çocuğun aileden aldı ğı } \\
\text { destek }\end{array}$ & .93 & .79 \\
\hline $\begin{array}{l}55 \text { (56). Sınıfımdaki diğer öğrencilerle } \\
\text { karşılaştırıldığı zaman, bu çocuğun zihinsel işlevleri }\end{array}$ & .89 & .93 \\
\hline $\begin{array}{l}\text { 56(57). Sınıfımdaki diğer öğrencilerle } \\
\text { karşılaştırıldığı zaman, bu çocuğun genel sınıf } \\
\text { davranışı }\end{array}$ & .89 & .86 \\
\hline
\end{tabular}

* Faktör yükleri. 10 dan küçük olan maddelerin faktör yükleri tabloda gösterilmemiştir.

** Orijinal ölçeğin madde numaraları

Madde analizi: 613 çocuk için doldurulan SBDS ile toplanan verilerle; alt-üst grup ortalamaları farkina, madde puanlari ile toplam puanlar arasındaki korelasyona ve ölçüt geçerliğine bakılmıştır: a) SBÖ,
PDÖ ve AYÖ Ölçeklerinde yer alan her madde için alt ve üst $\% 27 ' l i k$ grupların puan ortalamaları arasında fark olup olmadığına ilişkisiz örnekler için $t$ testi ile bakılmıştır. b) Her ölçekte yer alan her maddenin, o alt 
ölçeğin toplam puanı yordama gücünü belirleyebilmek için, her maddenin o ölçekten elde edilen toplam puan ile ilişkisine bakılmış ve madde toplam korelasyon katsayıları hesaplanmıştır. SBÖ, PDÖ ve AYÖ'de yer alan maddelerin madde analizi (t-testi) sonuçları Tablo 5'de verilmiştir. Bu tabloda görüldüğü gibi ilişkisiz örneklemler için $t$ testi sonucunda SBÖ, PDÖ ve AYÖ ölçeklerindeki tüm maddelerin, alt ve üst grupları, sahip oldukları beceri ve davranışlar açısından ayırt ettikleri bulunmuştur. Ayrıca tüm ölçekte yer alan maddelerin, madde toplam korelasyon katsayılarının da .40 ile .77 arasında değiştiği görülmüştür (Madde toplam korelasyon katsayıları tablo 2, 3 ve $4^{\prime}$ te verilmiştir).

Tablo 5

SBDS'inde Yer Alan Maddelerin Madde Analizi Sonuçları.

\begin{tabular}{|c|c|c|c|c|c|c|c|c|}
\hline \multicolumn{3}{|c|}{ SBÖ } & \multicolumn{3}{|c|}{ PDÖ } & \multicolumn{3}{|c|}{ AYÖ } \\
\hline Madde no & $t$ & $p$ & Madde no & $t$ & $p$ & Madde no & $T$ & $p$ \\
\hline 1 & 15.555 & .000 & 31 & 27.028 & .000 & 49 & 81.178 & .000 \\
\hline 2 & 22.655 & .000 & 32 & 18.449 & .000 & 50 & 57.523 & .000 \\
\hline 3 & 28.725 & .000 & 33 & 21.090 & .000 & 51 & 78.086 & .000 \\
\hline 4 & 14.187 & .000 & 34 & 17.903 & .000 & 52 & 58.787 & .000 \\
\hline 5 & 18.718 & .000 & 65 & 30.112 & .000 & 53 & 81.188 & .000 \\
\hline 6 & 20.507 & .000 & 36 & 25.100 & .000 & 54 & 74.754 & .000 \\
\hline 7 & 28.947 & .000 & 37 & 23.406 & .000 & 55 & 41.010 & .000 \\
\hline 8 & 23.268 & .000 & 38 & 20.597 & .000 & 56 & 67.046 & .000 \\
\hline 9 & 31.181 & .000 & 39 & 10.093 & .000 & 57 & 49.644 & .000 \\
\hline 10 & 22.924 & .000 & 40 & 31.050 & .000 & & & \\
\hline 11 & 21.596 & .000 & 41 & 26.173 & .000 & & & \\
\hline 12 & 15.748 & .000 & 42 & 21.597 & .000 & & & \\
\hline 13 & 14.775 & .000 & 43 & 25.647 & .000 & & & \\
\hline 14 & 22.225 & .000 & 44 & 16.928 & .000 & & & \\
\hline 15 & 35.051 & .000 & 45 & 17.683 & .000 & & & \\
\hline 16 & 28.695 & .000 & 46 & 20.976 & .000 & & & \\
\hline 17 & 7.586 & .000 & 47 & 33.890 & .000 & & & \\
\hline 18 & 12.460 & .000 & 48 & 26.072 & .000 & & & \\
\hline 19 & 19.712 & .000 & & & & & & \\
\hline 20 & 21.575 & .000 & & & & & & \\
\hline 21 & 20.292 & .000 & & & & & & \\
\hline 22 & 15.880 & .000 & & & & & & \\
\hline 23 & 30.134 & .000 & & & & & & \\
\hline 24 & 23.815 & .000 & & & & & & \\
\hline 25 & 17.488 & .000 & & & & & & \\
\hline 26 & 24.917 & .000 & & & & & & \\
\hline 27 & 27.135 & .000 & & & & & & \\
\hline 28 & 32.029 & .000 & & & & & & \\
\hline 29 & 37.298 & .000 & & & & & & \\
\hline 30 & 23.018 & .000 & & & & & & \\
\hline
\end{tabular}

Alt ölçeklerin Birbirleri İle İlişkisi: Geçerlik çalışmaları kapsamında, SBDS de yer alan üç alt ölçeğin birbirleri ile ilişkisi incelenmiş ve Türkçe formun sosyal beceri, problem davranış ve akademik yeterlilik puanlarının ilişkisi Pearson korelasyon katsayıs ile hesaplanmıştır. Analiz sonuçlarına göre, sosyal beceri ölçeği toplam puanları ile problem davranışlar ölçeği toplam puanları arasında yüksek ve ters bir ilişki ( $r=-$ .713, $\mathrm{p}=.000)$; akademik yeterlilik puanları ile de yüksek ve doğru bir ilişki vardır ( $r=$ .712, $r=.000)$. Benzer şekilde 
problem davranış puanları ile akademik yeterlilik puanlarl arasında da anlamlı ve ters bir ilişki olduğu görülmüştür $(r=$ $.485, \mathrm{p}=.000)$.

\section{B) Güvenirlik Çalışması:}

SBDS'de yer alan 3 ölçeğin iç tutarlılığı, Cronbach Alfa katsayıları hesaplanarak test edilmiştir. Sosyal beceriler ölçeğinin toplam puan için Cronbach Alfa katsayısı .96, birinci faktör için .91, ikinci faktör için .93 ve üçüncü faktör için .84 olarak bulunmuştur. Problem davranışlar ölçeğinin toplam puan için Cronbach Alfa katsayısı.90, birinci faktör için .93, ikinci faktör için .86 olarak bulunmuştur. Akademik yeterlilik ölçeğinin toplam puan için Cronbach Alfa katsayısı ise .97 olarak bulunmuştur. Tüm analizlerin sonuçları, SBDS'nin ilköğretim 1.-3. sinıf öğrencilerinin sosyal becerilerini değerlendirmede geçerli ve güvenilir bir ölçek olarak kullanılabileceğini göstermektedir.

\section{Verilerin Toplanması ve Analizi}

Araştırma grubunda yer alan iki ilköğretim okulundaki 33 öğretmen, sınif listelerindeki her öğrencinin sosyal becerilerini, problem davranışlarını ve akademik yeterliliklerini SBDS kullanarak değerlendirmişlerdir. Bu araştırmanın birinci amacı olan kaynaştırma öğrencisi olan ve olmayan öğrencilerin elde ettikleri sosyal beceri puanları ortalamaları arasında anlamlı bir farklılık olup olmadığı, veriler tek yönlü varyans analizi (ANOVA) ile analiz edilerek incelenmiştir. Araştırmada ikinci olarak, SBDS ölçeklerinden elde edilen puanların, öğrencilerin cinsiyeti ile sinıf düzeylerine göre farklılaşıp farklılaşmadığını belirlemek amacıyla her değişken için ayrı ayrı varyans analizi yapılmıştır.

\section{Bulgular}

\section{Kaynaştırma Öğrencileri ile Akranlarinin Sosyal Becerilerinin Karşılaştırılması \\ İlköğretim okullarına devam} eden özel gereksinimli öğrenciler ile diğer öğrencilerin sosyal beceri, davranış problemleri ve akademik yeterlilik puanlarının farklılaşıp farklılaşmadığını saptamak için yapılan ANOVA testleri sonucunda elde edilen bulgular Tablo 6'da gösterilmiştir. Tablo incelendiğinde kaynaştırma öğrencisi olan ve olmayan öğrencilerin, sosyal beceri ölçeği toplam ve alt ölçek puanları, problem davranış ölçeğinin toplam ve alt ölçek puanları ile akademik yeterlilik puanları arasında anlamlı fark olduğu görülmektedir. Kaynaştırma öğrencilerinin sBö toplam puan ve faktör puanları ile akademik yeterlilik puanlarl ortalamaları, akranlarının puan ortalamalarından anlamlı düzeyde düşük; problem davranış ölçeği toplam puanları ile faktör puanları ise ortalamalari ise anlamlı düzeyde yüksektir.

\section{Tablo 6}

Kaynaștırma öğrencisi olan ve olmayan öğrencilerin SBÖ, PDÖ ve AYÖ Toplam ve Faktör Puanları Arasındaki Farkın Anlamlılığı İ̧in ANOVA Sonuçları. 


\begin{tabular}{|c|c|c|c|c|c|c|c|}
\hline & Faktörler & Grup & $\mathbf{N}$ & $\bar{x}$ & ss & $\mathbf{F}$ & $p$ \\
\hline \multirow{8}{*}{ SBÖ } & \multirow{2}{*}{ İşbirliği } & KÖ & 53 & 9.01 & 5.39 & \multirow[t]{2}{*}{27.903} & \multirow[t]{2}{*}{.000} \\
\hline & & Diğer & 604 & 13.92 & 6.55 & & \\
\hline & \multirow{2}{*}{ Atılganlık } & KÖ & 53 & 8.03 & 4.77 & \multirow[t]{2}{*}{83.208} & \multirow[t]{2}{*}{.000} \\
\hline & & Diğgr & 604 & 14.68 & 5.09 & & \\
\hline & \multirow{2}{*}{$\begin{array}{l}\text { Kendini } \\
\text { Kontrol }\end{array}$} & KÖ & 53 & 7.39 & 3.16 & \multirow[t]{2}{*}{32.782} & \multirow[t]{2}{*}{.000} \\
\hline & & Diğer & 604 & 10.01 & 3.17 & & \\
\hline & \multirow{2}{*}{ Toplam } & KÖ & 53 & 24.45 & 9.75 & \multirow[t]{2}{*}{71.745} & \multirow[t]{2}{*}{.000} \\
\hline & & Diğer & 604 & 38.61 & 11.79 & & \\
\hline \multirow{7}{*}{ PDÖ } & \multirow{2}{*}{$\begin{array}{l}\text { Dışsallaştırıl } \\
\text { mış } \\
\text { Davranışlar }\end{array}$} & KÖ & 53 & 10.30 & 6.26 & \multirow[t]{2}{*}{60.752} & \multirow[t]{2}{*}{.000} \\
\hline & & Diğer & 604 & 4.48 & 5.08 & & \\
\hline & \multirow{2}{*}{$\begin{array}{l}\text { İçselleştirilm } \\
\text { iş Davranışlar }\end{array}$} & KÖ & 53 & 6.81 & 2.91 & \multirow[t]{2}{*}{27.949} & \multirow[t]{2}{*}{.000} \\
\hline & & Dišar & 604 & 409 & 363 & & \\
\hline & \multirow{3}{*}{ Toplam } & KÖ & 53 & 17.11 & 7.08 & \multirow[t]{3}{*}{74.259} & \multirow[t]{3}{*}{.000} \\
\hline & & & & & & & \\
\hline & & Diğer & 604 & 8.57 & 6.87 & & \\
\hline \multirow{2}{*}{ AYÖ } & \multirow{2}{*}{ Toplam } & KÖ & 53 & 18.15 & 7.24 & \multirow[t]{2}{*}{100.336} & \multirow[t]{2}{*}{.000} \\
\hline & & Diğer & 604 & 32.27 & 10.01 & & \\
\hline
\end{tabular}

Cinsiyet ve Sınıf Düzeyi Değişkenlerinin SBDS Ölçek ve Alt Ölçek Puanları Üzerindeki Etkisinin Belirlenmesi

a. Cinsiyet: 613 öğrenciden toplanan veriler, sosyal beceriler, problem davranışlar ve akademik yeterlilik puanları ortalamalarının öğrencilerin cinsiyetine göre farklılaşıp farklılaşmadığını belirlemek için, tek yönlü varyans analizi ile test edilmiştir. 613 öğrenci için yapılan analiz sonucunda, kız ve erkek öğrencilerin SBÖ'den aldıkları toplam ve alt ölçek puanları ile PDÖ'den aldıkları toplam puanlar arasinda anlamlı bir fark ortaya çıktığı görülmüştür. Kız öğrencilerinin SBÖ toplam ve alt ölçek puan ortalamaları erkek öğrencilerden fazla, PDÖ toplam ve alt ölçek puanları ise erkek öğrencilerden azdır. İki grup öğrencinin akademik yeterlilik puanları karşılaştırıldığı zaman ise kızların akademik yeterlilikleri ile erkeklerin akademik yeterlilikleri arasında anlamlı fark olmadığı görülmüştür. 
Cinsiyetin

SBDS

puanları üzerinde etkili olup olmadığı, tüm grup için araştırıldıktan sonra, aynı analizler kaynaştırma öğrencileri için tekrarlanmıştır. Cinsiyete göre yapılan ANOVA sonuçları Tablo 7'de toplu olarak verilmiştir. Bu tablo incelendiği zaman, kaynaştırma öğrencilerinin, sosyal beceri ölçeğinin işbirliği ve kendini kontrol faktör puanlarında cinsiyete göre farklılaşma olmadığı, ancak kız ve erkek öğrencilerin atılganlık faktörü ile toplam puan ortalamalarınn birbirlerinden anlamlı derecede farklılaştığı görülmüştür. Kız öğrencilerin hem atılganlık hem de hem de sosyal beceri toplam puanları erkeklerin puanlarından yüksektir. Kaynaştırma öğrencilerinin problem davranışlarına göz atıldığı zaman, kız ve erkek öğrencilerin dışsallaştırılmış davranışlar faktör puanı ve toplam puan ortalamalarının anlamlı şekilde farklılaştığı, erkek öğrencilerin bu puanlarının ortalamalarının klzlardan fazla olduğu görülmüştür. Erkek ve klz öğrencilerin içselleştirilmiş davranışlar ile akademik yeterlilik puanları arasında anlamlı fark bulunamamıştır.

\section{Tablo 7}

Kız ve Erkek Öğrencilerin SBÖ, PDÖ ve AYÖ Toplam ve Faktör Puanları Arasındaki Farkı Gösteren ANOVA Testi Sonuçları.

\begin{tabular}{|c|c|c|c|c|c|c|c|c|}
\hline \multirow[t]{2}{*}{ Grup } & \multirow[t]{2}{*}{ Ölçek } & & \multicolumn{2}{|c|}{ KIz } & \multicolumn{2}{|c|}{ Erkek } & \multirow[t]{2}{*}{$\mathbf{F}$} & \multirow[t]{2}{*}{$p$} \\
\hline & & Alt Ölçek & $\mathbf{x}$ & ss & $\mathbf{x}$ & ss & & \\
\hline \multirow{8}{*}{$\begin{array}{l}\text { Tüm Grup } \\
\mathbf{N} \\
613 \\
\text { Kız } \\
282 \\
\text { Erkek }=331\end{array}$} & \multirow{4}{*}{ SBÖ } & İşbirliği & 14.71 & 6.25 & 12.46 & 6.72 & $\begin{array}{c}18.30 \\
2\end{array}$ & .000 \\
\hline & & Atılganlık & 15.15 & 5.19 & 13.21 & 5.44 & $\begin{array}{c}20.25 \\
4\end{array}$ & .000 \\
\hline & & $\begin{array}{l}\text { Kendini } \\
\text { kontrol }\end{array}$ & 10.24 & 2.84 & 9.38 & 3.53 & $\begin{array}{c}10.73 \\
5\end{array}$ & .000 \\
\hline & & Toplam & 40.12 & 11.84 & 35.06 & 12.19 & $\begin{array}{c}26.84 \\
3\end{array}$ & .000 \\
\hline & \multirow[t]{3}{*}{ PDÖ } & $\begin{array}{l}\text { Dışsallaştırı } \\
\text { lmıs } \\
\text { davranışlar }\end{array}$ & 3.62 & 4.34 & 6.14 & 6.99 & $\begin{array}{c}34.33 \\
5\end{array}$ & .000 \\
\hline & & $\begin{array}{l}\text { İçselleştiril } \\
\text { miş } \\
\text { davranışlar }\end{array}$ & 3.68 & 3.26 & 4.87 & 3.88 & $\begin{array}{c}16.29 \\
7\end{array}$ & .000 \\
\hline & & Toplam & 7.31 & 6.33 & 11.02 & 7.63 & $\begin{array}{c}41.73 \\
5\end{array}$ & .000 \\
\hline & AYÖ & $\begin{array}{l}\text { Akademik } \\
\text { yeterlilik }\end{array}$ & 31.79 & 10.77 & 30.41 & 10.37 & 2.615 & .106 \\
\hline \multirow{4}{*}{$\begin{array}{l}\text { KÖ } \\
\mathbf{N} \\
=53\end{array}$} & \multirow{4}{*}{ SBÖ } & İşbirliği & 10.50 & 5.48 & 8.37 & 5.29 & 1.755 & .191 \\
\hline & & Atılganlık & 10.62 & 3.48 & 6.91 & 4.86 & 7.578 & .008 \\
\hline & & $\begin{array}{l}\text { Kendini } \\
\text { kontrol }\end{array}$ & 8.62 & 2.75 & 6.86 & 3.21 & 3.631 & .062 \\
\hline & & Toplam & 29.75 & 7.72 & 22.16 & 9.73 & 7.620 & .008 \\
\hline
\end{tabular}




\begin{tabular}{|c|c|c|c|c|c|c|c|c|}
\hline $\begin{array}{l}\text { Kız } \\
16 \\
\text { Erkek = } 37\end{array}$ & PDÖ & $\begin{array}{l}\text { Dışsallaştırı } \\
\text { lmış } \\
\text { davranışlar }\end{array}$ & 7.25 & 5.63 & 11.62 & 6.12 & 5.957 & .018 \\
\hline & & $\begin{array}{l}\text { İçselleştiril } \\
\text { miş } \\
\text { davranışlar }\end{array}$ & 6.43 & 2.73 & 6.97 & 3.02 & .372 & .545 \\
\hline & & Toplam & 13.68 & 6.72 & 18.59 & 6.80 & 5.856 & .019 \\
\hline & AYÖ & $\begin{array}{l}\text { Akademik } \\
\text { yeterlilik }\end{array}$ & 17.25 & 4.13 & 18.54 & 8.25 & .350 & .557 \\
\hline
\end{tabular}

b. Sınıf düzeyi: Çalışmanın denekleri birinci, ikinci ve üçüncü sınıf öğrencilerinden oluşmaktadır. SBDS nin üç alt ölçeğinden alınan puanların, öğrencilerin sınıf düzeyine göre farklılaşıp farklılaşmadığı da ANOVA ile test edilmiş ve sonuçlar toplu olarak Tablo 8'de verilmiştir. Tabloda görüldüğü gibi, SBÖ toplam puanları ile işbirliği alt ölçeği puanları sınıf düzeyine göre farklılaşmış; bu puanların öğrencilerin sınıf düzeyine göre değiştiği, sınıf düzeyi arttıkça işbirliği puanları ve sosyal beceri toplam puanlarının da arttığı bulunmuştur. Problem davranış toplam puanları ortalamaları ve içselleştirilmiş davranışlar arasinda ANOVA sonucunda sinıf düzeyine göre anlamlı farklılık ortaya çıkmış, ancak farkın hangi gruptan kaynaklandığını bulmak amacıyla yapılan Dunnet testi (varyansların homojen olmaması nedeniyle kullanilan post-hoc test) sonuçları incelendiği zaman (Green, Salkind ve Akey, 1997) sadece birinci sinıfların içselleştirilmiş

davranış puanlarının üçüncü sınıflardan farklılaştığı görülmüştür. Bunun yanı sira Dunnet testi sonucuna göre problem davranış toplam puanlarının sınıf düzeyine göre anlamlı fark yaratmadığı bulunmuştur. Benzer bir şekilde tüm grubun akademik yeterlilik puanları da sınıf düzeyine göre farklılaşmamıştır.

Tablo 8

SBÖ, PDÖ ve AYÖ Toplam ve Faktör Puanlarının Öğrencilerin Sınıf Düzeyine Göre Farklılaşmasını Gösteren

ANOVA Testi Sonuçarı.

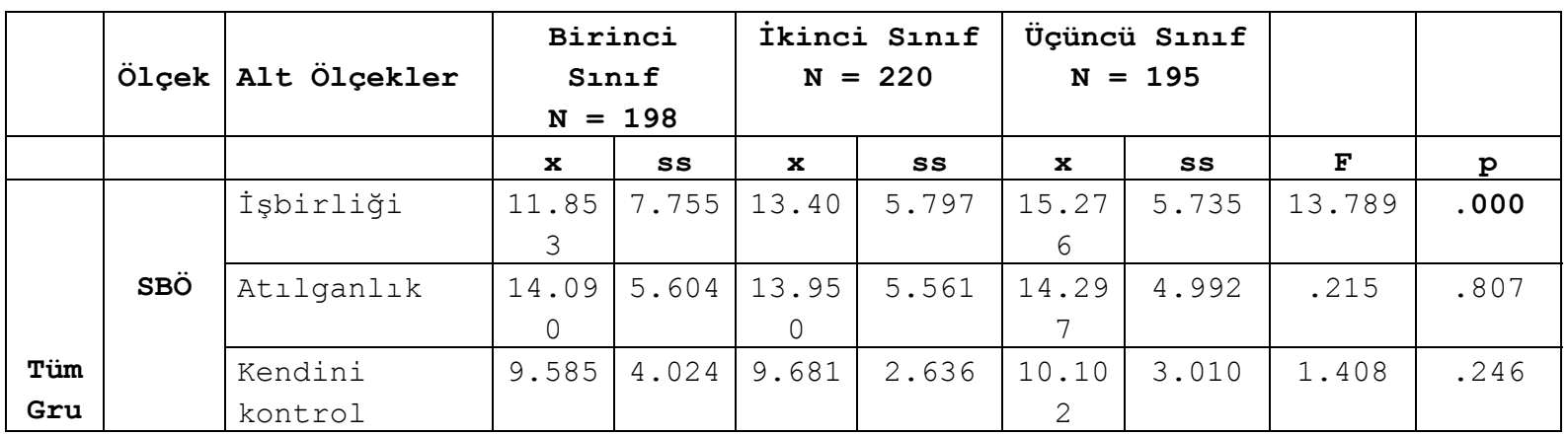




\begin{tabular}{|c|c|c|c|c|c|c|c|c|c|c|}
\hline \multirow[t]{5}{*}{$\mathrm{p}$} & & Toplam & $\begin{array}{c}35.53 \\
0\end{array}$ & $\begin{array}{c}13.47 \\
2\end{array}$ & $\begin{array}{c}37.04 \\
0\end{array}$ & 11.244 & $\begin{array}{c}39.67 \\
6\end{array}$ & 11.850 & 5.823 & .003 \\
\hline & \multirow{3}{*}{ PDÖ } & $\begin{array}{l}\text { Dışsallaştırı } \\
\text { lmış } \\
\text { davranışlar }\end{array}$ & 5.025 & 5.32 & 4.768 & 5.631 & 5.184 & 5.372 & .310 & .733 \\
\hline & & $\begin{array}{l}\text { İçelleştiril } \\
\text { miş } \\
\text { davranışlar }\end{array}$ & 5.489 & 4.293 & 3.731 & 3.147 & 3.815 & 3.205 & 15.525 & .000 \\
\hline & & Toplam & $\begin{array}{c}10.51 \\
5\end{array}$ & 6.786 & 8.500 & 7.265 & 9.000 & 7.705 & 4.275 & .014 \\
\hline & AYÖ & $\begin{array}{l}\text { Akademik } \\
\text { yeterlilik }\end{array}$ & $\begin{array}{c}30.48 \\
9\end{array}$ & $\begin{array}{c}10.50 \\
9\end{array}$ & $\begin{array}{c}31.98 \\
1\end{array}$ & 10.488 & $\begin{array}{c}30.56 \\
9\end{array}$ & 10.719 & 1.335 & .264 \\
\hline \multirow{8}{*}{ Kö } & \multirow{4}{*}{ SBÖ } & İşirliği & 8.23 & 5.44 & 8.57 & 5.76 & 10.05 & 5.03 & .551 & .580 \\
\hline & & Atılganlık & 6.00 & 4.54 & 8.61 & 5.38 & 8.78 & 3.98 & 1.611 & .210 \\
\hline & & $\begin{array}{l}\text { Kendini } \\
\text { kontrol }\end{array}$ & 6.38 & 3.70 & 7.23 & 3.19 & 8.26 & 2.62 & 1.427 & .250 \\
\hline & & Toplam & 20.61 & 10.75 & 24.42 & 10.70 & 27.10 & 7.23 & 1.759 & .183 \\
\hline & \multirow{3}{*}{ PDÖ } & $\begin{array}{l}\text { Dışsallaştırı } \\
\text { lmış } \\
\text { davranışlar }\end{array}$ & 11.53 & 5.68 & 11.04 & 6.46 & 8.63 & 6.37 & 1.081 & .347 \\
\hline & & $\begin{array}{l}\text { İçelleştiril } \\
\text { miş } \\
\text { davranışlar }\end{array}$ & 7.30 & 2.59 & 6.52 & 3.41 & 6.78 & 2.61 & .283 & .755 \\
\hline & & Toplam & 18.84 & 6.10 & 17.57 & 8.00 & 15.42 & 6.60 & .973 & .385 \\
\hline & AYÖ & $\begin{array}{l}\text { Akademik } \\
\text { yeterlilik }\end{array}$ & 17.30 & 7.70 & 20.09 & 7.62 & 16.57 & 6.32 & 1.306 & .280 \\
\hline
\end{tabular}

SBDS puanlarının sınıf düzeyine göre ne kadar farklılaşı farklılaşmadığını araştırmak amacıyla yapılan analizler kaynaştırma öğrencileri için bir kez daha tekrarlandığı zaman, SBDS nin alt ölçek puanlarının engelli öğrencilerin sınıf düzeyine göre farklılaşmadığı görülmüştür.

\section{Tartışma}

$\mathrm{Bu}$ çalışmada öncelikle SBDS'nin Türkçe formunun psikometrik özellikleri araştırılmış ve sınıf öğretmenlerinin toplam 613 öğrenciyi sonucunda elde temel geçerlik ve güvenirlik analizleri yapılmıştır. Geçerlik çalışması için öncelikle SBDS'nin üç alt ölçeği için ayrı ayrı faktör analizleri yapılmış ve sosyal beceri ölçeğinin üç faktörlü yapısının korunduğu, problem davranış ölçeğinin ise orijinal ölçekteki üç faktörlü yapısının, Türkçe formda iki faktörlü bir yapıya dönüştüğü görülmüştür. Faktör yapısındaki değişiklikler iki nedene bağlı olarak ortaya çıkmış olabilir. 


\begin{abstract}
Birincisi, iki kültür arasındaki farklılardır ve kültürel farklılıklara bağlı olarak maddelere verilen tepki örüntülerindeki farklılıklar, çevirisi yapılmış aracın psikometrik özelliklerine yansıyabilir (Akt., Kaner ve Çiçekçi, 2000). İkinci nedenin ise verilerin toplandığı yaş grubu ile ilgili olduğu düşünülmektedir. Bu çalışmada SBDS'nin, anasınıfı-6. sınıf için geliştirilen öğretmen formu kullanılmıştır. Dolayısıyla orijinal ölçek için yapılan faktör analizi çalışmaları, bu yaş grubundan elde edilen verilerle gerçekleştirilmiş, böylece sosyal beceriler ve problem davranişlar alt ölçeklerinin faktör yapıları ortaya çıkarılmıştır. Bu çalışmada ise verilerin toplandığı yaş grubu, bir, iki ve üçüncü sınıf öğrencilerinden oluşmaktadır. Araştırmalar yaşa ve cinsiyete göre farklı faktörlerin oluştuğunu gösteren bulgular vermektedir (Akt., Kaner ve Çiçekçi, 2000). $\mathrm{Bu}$ nedenlerle kültürel özellikler ve çalışma grubunun yaşına bağlı olarak iki alt ölçeğin faktör yapılarında değişiklik olduğu kabul edilebilir.
\end{abstract}

Geçerlik çalışmalarının yanı sıra SBDS Türkçe Formu alt ölçekleri için Cronbach Alfa iç tutarlılık katsayıları hesaplanmış ve üç alt ölçek için elde edilen alfa değerlerinin yüksek olduğu görülmüştür. Orijinal ölçek için yapılan ölçüt geçerliliği, testtekrar test güvenirliği ile değerlendiriciler arası güvenirlik katsayıları, öğretmenlerinin, sinıf kullanarak her çocuğu bir kez değerlendirme dışında form doldurmak istememeleri nedeniyle, bu çalışmada hesaplanamamıştır.

SBDS'nin Türkçe Formu için yapılan güvenirlik çalışmaları, madde analizleri ve diğer çalışmalardan elde edilen sonuçlar ile orijinal formdan elde edilen sonuçlar arasında tutarlılık olduğu görülmektedir. Yapılan geçerlik ve güvenirlik analizleri, SBDS'nin Türkçe Formu ile ilkokul öğrencilerinin (birinci - üçüncü sinif) sosyal becerilerinin geçerli ve güvenilir şekilde değerlendirilebileceğini

göstermektedir. Bu nedenle, Türkçe Form, engelli olan ve olmayan öğrencilerin sosyal becerilerin değerlendirilmesinin yanı sıra, müdahale programları hazırlamak ve uygulanan sosyal beceri öğretimi programlarının etkisini değerlendirebilmek amacıyla da kullanılabilir. İleride yapılacak çalışmalarda daha büyük gruplardan ve farklı engel gruplarından veri toplanarak SBDS Türkçe Formu'nun engelli olan ve olmayan çocuklar için normları çıkarılmalı ve geçerlik güvenirlik çalışmaları da yinelenmelidir.

$$
\text { Çalışmanın }
$$

bulguları,

kaynaştırma öğrencilerinin sosyal

beceriler, problem dav-ranışlar toplam ve ortalamaları ile

ölçek

akademik yeterlilik puan ortalamalarının akranlarından anlamlı derecede farklılaştığını göstermektedir. $\mathrm{Bu}$ sonuçlara göre kaynaştırma öğrencilerinin sosyal becerileri ve akademik yeterlilikleri engelli olmayan akranlarından daha az, problem davranışları ise daha fazladır. Engelli olan ve olmayan çocukların sosyal becerilerini karşılaştırmalı olarak inceleyen çalışmalarda engelli çocukların sosyal becerilerinin akranlarına göre yetersiz olduğu görülmektedir 
(Gresham, 1997; Sabornie ve Beard, 1990; Uysal, 2003). Gresham ve Reschly (1987) ve Gresham, Elliott ve Black'e (1987) göre, öğrenme güçlüğü olan çocuklar ile hafif derecede zihinsel engelli çocukların sosyal beceri puanlarının engelii olmayan akranlarından yaklaşık olarak 2 standart sapma geride olduğu bulunmuştur (Akt., Gresham ve Elliot, 1990). Bu çalışmanın sonuçları da, kaynaştırma öğrencilerinin, sadece sınıf ortaminda bulunarak ve akranları ile etkileşime girerek sosyal becerileri edinemedikleri; bu nedenle kaynaştırma uygulamalarının yararını artırmak ve sosyal becerilerin gelişimini sağlamak için, sosyal beceri öğretimi yapılmasının gerekli olduğu şeklinde yorumlanabilir.

Kaynaştırma sergiledikleri

öğrencilerinin olumsuz/problem davranışların akranlarından daha fazla olduğu ve bu davranışların çocukların akranları ve yetişkinlerle ilişkilerini olumsuz yönde etkilediği kabul edilmektedir. Örneğin zihinsel engelli bireyler akranlarından daha fazla problem davranış sergilemekte (Freund ve Reiss, 1991; Semmel ve Gao, 1992) ve zeka düzeyinin düşük olması problem davranışların ortaya çıkma olasılığını artırmaktadır (Russelı ve Forness, 1985). Benzer şekilde işitme engelli çocuklarla işiten çocukların karşılaştırıldığı bir çalışmada işitme engelli çocukların, hem içselleştirilmiş, hem de dışsallaştırılmış problem davranışları, akranlarından fazla sergiledikleri bulunmuştur (David, Elfenbein, Schum ve Bentler, 1998). Bu sonuçlar temel alındığında araştırmanın problem davranışlara ilişkin bulgusunun, beklendik ve alanyazınla tutarlı bir bulgu olduğu söylenebilir. Ancak, bu araştırmanın problem davranışlara ilişkin bulgusu dikkatli yorumlanmalıdır: Kaynaştırma öğrencilerinin problem davranıslarının fazla olması çocukların engelli / özel gereksinimli olmalarıyla açıklanabilir; ancak, kaynaştırma ortamlarında sergilenen problem davranışlar çoğu zaman, uygun olmayan öğretim ortamı, müfredat programının çocukların özelliklerine göre uyarlanmaması, öğretmenin sınıf yönetimi gibi değişkenlerin etkisi ile de ortaya çıkabilmektedir (Marzano ve Marzano, 2003). Ülkemizdeki kaynaştırma uygulamalarının en önemli sorunu, öğretmenlerin kaynaştırma uygulamaları hakkında bilgi ve deneyimlerinin olmamasına bağlı olarak bu çocukların öğretimsel gereksinimlerin karşılanamamasıdır (Kargın, Acarlar ve Sucuoğlu, 2004). Dolayısıyla bu araştırmaya katılan kaynaştırma öğrencilerinin problem davranıslarının fazla olması kaynaştırma uygulamalarının sınırlılıklarına bağlı olarak da açıklanabilir.

İki grubun akademik yeterlik puanları arasında ortaya çıkan anlamlı fark, iki nedenle beklenen sonuçtur. Birinci neden, çalışma grubunda yer alan kaynaştırma öğrencilerinin çoğunluğunun rehberlik araştırma merkezlerinden, öğrenme ve bilişsel özellikleri nedeniyle "kaynaştırma öğrencisi" tanısı almış olmaları, diğerlerinin ise sürekli ve değişmeyen şekilde ortaya çıkan başarısızlıklarının öğretmenleri tarafından 
bildirilmesidir. Bu durum, her iki grup öğrencinin de öğrenmeye ilişkin sorunları olduğunu göstermekte, buna bağlı olarak da akademik yeterliliklerinin akranlarından daha az olması beklenmektedir. İkinci neden ise "sosyal beceriler, $\begin{gathered}\text { problem } \\ \text { davranışlar ve akademik beceriler }\end{gathered}$ arasında ilişki" ile açlklanabilir. Sosyal beceri yetersizlikleri akademik yetersizliklerle ve problem davranışlarla birlikte ortaya çıkmaktadır (Eister, Walker, Severson, Black ve Todis, 1987; Elliott, Gresham, Freeman ve McCloskey, 1988; Fifield, 1988; Walker, 1986: Akt., Gresham ve Elliot, 1990). Bu çalışmada da SBDS'nin Türkçe Formu ile toplanan verilerle, üç alt ölçek arasındaki ilişki incelendiği zaman, sosyal becerilerle akademik beceriler arasında doğru, problem davranışlar arasında ters ilişki olduğu bulunmuştur. Bu sonuç, alanyazında sıklıkla vurgulanan, sosyal beceriler, akademik başarı ve problem davranışlar ilişkisini göstermekte; bir başka deyişle sosyal becerilerin az olması ve problem davranışların fazla olmasının akademik yetersizliği ortaya çıkardı ğını düşündürmektedir (Chadsey-Rusch, 1992; Gresham, 1997; Sargent, 1991; Zirpoli ve Melloy, 1997).

Kaynaştırma

öğrencilerinin SBDS'nden elde ettikleri puanların cinsiyet ve sınıf düzeyine göre değişip değişmediğini belirlemek, bu araştırmanın ikinci amacıdır. $\mathrm{Bu}$ amaca ulaşabilmek için analizler önce tüm araştırma grubu için yapılmış daha sonra aynı analizler kaynaştırma öğrencileri için tekrarlanmıştır. Analiz sonuçlarına göre cinsiyet değişkeni tüm gurubun sosyal becerileri üzerinde etkilidir ve kız öğrencilerin sosyal becerileri erkeklerden fazla, problem davranışları ise erkeklerden azdır.

Gresham ve Elliot (1990), ölçeğin psikometrik özelliklerini belirlemek için yaptıkları büyük ölçekli çalışmada, SBDS'nin annebaba, öğretmen ve öğrenci formlarından elde edilen verileri ayrı ayrı analiz ettikleri zaman, kız öğrencilerin daha yüksek sosyal beceri puanı aldıklarını bulmuşlardır. Aynı çalışmada, cinsiyetin problem davranışlar üzerindeki etkisi araştırıldığında kız-erkek farkı belirgin bir şekilde ortaya çıkmış, her sınıf düzeyindeki erkek öğrencilerin kızlardan daha fazla problem davranış sergiledikleri görülmüştür. Araştırmacılar, kızların sosyal becerilerinin tutarlı olarak erkeklerden fazla, problem davranışlarının ise az olmasını, erkek öğrencilerin problem davranısları sergilemelerinin, sosyal becerilerin gelişimi ve kullanımını engellediği şeklinde yorumlamışlardır. Akademik yeterlilikler açısından kızlarla erkekler arasinda anlamlı fark ortaya çıkmamıştır.

Kaynaştırma öğrencileri için cinsiyet, SBDS puanları üzerinde genel olarak benzer etkiye sahiptir. Kız öğrencilerin toplam sBö puanları ile atılganlık boyutu puanları erkeklerden fazladır, ancak işbirliği ve kendini kontrol boyutlarında kız ve erkek öğrencilerin puan ortalamaları arasinda fark yoktur. Erkeklerin PDÖ toplam puanları (anlamlı fark 
olmasa da) kızların puanlarından yüksektir, Dışsallaştırılmış davranışlar boyutunda bu fark anlamlı bir şekilde ortaya çıkarken, içselleştirilmiş davranışlar boyutunda kız ve erkek öğrencilerin puanlarının farklılaşmadığı görülmüştür. Oysa alanyazında problem davranışların ve sosyal becerilerin cinsiyete göre farklılaştığını gösteren çalışmalar bulunmakta (Gresham ve Elliot, 1990; Merrell, 1994), özellikle dışsallaştırılmış davranışlar ve saldırganlığın erkeklerde daha fazla ortaya çıktığı (Çiçekçi, 1999) savunulmaktadır. Poyraz-Tüy (1999), cinsiyet ve işitme engelinin, okul öncesi çocukların sosyal becerileri üzerinde ortak etkisi olmadığını, işitme engelinin sosyal becerilerde farklılığa yol açmasına karşın cinsiyetin problem davranişlar üzerinde farklılığa yol açmadığını bulmuştur. Engelli çocukların problem davranışlarının cinsiyete göre farklılaşmadığını gösteren araştırma bulgularının da olduğu görülmektedir (Çifci ve Cora-İnce, 2002; Sucuoğlu, 2003; Vostanis ve diğ., 1996 ).

613 öğrenciden toplanan verilerin analiz edildiği bu çalışmanın bulgularına göre, öğrencilerin sınıf düzeyi arttıkça tüm grubun sosyal beceri toplam puanları ile işbirliği puanları artmaktadır. Oysa, Gresham ve Elliot (1990) çalışmalarında SBDS puanlarının cinsiyet ve engelli olma değişkenlerine göre farklılaştığını ancak sınıf düzeyinin SBDS ölçek puanları üzerinde tutarlı bir farklılığa yol açmadığını belirtmişlerdir. okul öncesi çocukların sosyal becerilerinin, okul öncesi ve

\begin{abstract}
Anasınıfı Davranış Ölçekleri (Preschool and Kindergarten Behavior Scale) kullanilarak araştırıldığı iki çalışmada ise sosyal becerilerin yaşla arttığı (Merrell, 1994; Poyraz-Tüy, 1999) bulunmuştur. Bu çelişkili sonuçlar çalışma gruplarını oluşturan çocukların özellikleri ve yaş grupları ile çalışmalarda kullanılan ölçüm araçlarının farklılıklarına bağlı olarak açıklanabilir.
\end{abstract}

Bu araştırmada, öğrencilerin problem davranış toplam puanlarının sınıf düzeyine göre farklılaşmadığı ancak sadece birinci sınıf öğrencilerinin içselleştirilmiş davranışlar puan ortalamalarının diğerlerinden anlamlı düzeyde farklı olduğu ortaya çıkmıştır. Kaynaştırma öğrencilerinin problem davranışları toplam ve alt ölçek puanları, sınıf düzeyine göre farklılaşmamıştır. Sınıf düzeyinin ve buna bağlı olarak yaşın problem davranış puanlarında büyük bir farklılığa yol açmayacağı bazı çalışmalarda özellikle belirtilmişse de (Achenbach ve Edelbrok, 1986; Gresham ve Elliot, 1990); Sucuoğlu (2003) zihinsel engelli çocukların problem davranışlarının yaşa göre farklılaştığını ve çocukların yaşları büyüdükçe problem davranışlarının azaldığını bulmuştur.

\begin{tabular}{|c|c|c|}
\hline Akademik & yeterlilik & $(A Y)$ \\
\hline ölçekleri & genel & olarak \\
\hline öğrencilerin & gerçek & akademik \\
\hline aşarısını ö & lçer ve & \\
\hline ğrencilerin & akademik & yeterlik \\
\hline lçeklerinden & aldıkları & puanlar \\
\hline lenir. & & \\
\hline $\begin{array}{l}\text { klenir. } \\
\text { DS'nin }\end{array}$ & $\begin{array}{l}\text { Oysa bu } \\
\text { akademik }\end{array}$ & $\begin{array}{r}\text { çalışma } \\
\text { yeterl }\end{array}$ \\
\hline
\end{tabular}


grup için hem de özel gereksinimli öğrenciler için, sınıf düzeylerine göre farklılaşmamış, bir başka deyişle sınıf düzeyi arttıkça akademik yeterlilik artmamıştır. Bu durum SBDS'nin AY alt ölçeğinin özelliği nedeniyle ortaya çıkmaktadır. Çünkü AY ölçeği, bir başarı testi değildir, öğretmenler bu ölçeği kullanarak, her öğrencinin akademik özelliklerini sınıftaki arkadaşlarıyla karşılaştırarak

derecelendirmektedir (Gresham ve Elliot, 1990). Bu nedenle de AY puanlarının sınıf düzeyine göre artmasi ya da azalması beklenmemektedir.

$\mathrm{Bu}$ çalışmanın iki temel sınırlılığı bulunmaktadır. Birinci sınırlılık, çalışma grubunu oluşturan kaynaştırma öğrencilerinin sayısının oldukça az olmasıdır. Ancak araştırma, kaynaştırma uygulamaları yapılan ve öğretmenlerinin sınırlı da olsa sistematik destek hizmetleri aldığı iki ilköğretim okulunun öğrencilerini kapsayacak şekilde planlandığı için, diğer ilköğretim okullarına devam eden engelii öğrenciler "kaynaştırma öğrencisi" olarak bu çalışmaya katılmamıştır. İkinci sınırlılık ise "kaynaştırma öğrencisi" olarak tanımlanan özel gereksinimli engelleri, öğrencilerin yetersizlikleri hakkında bir bilgi edinilememiş

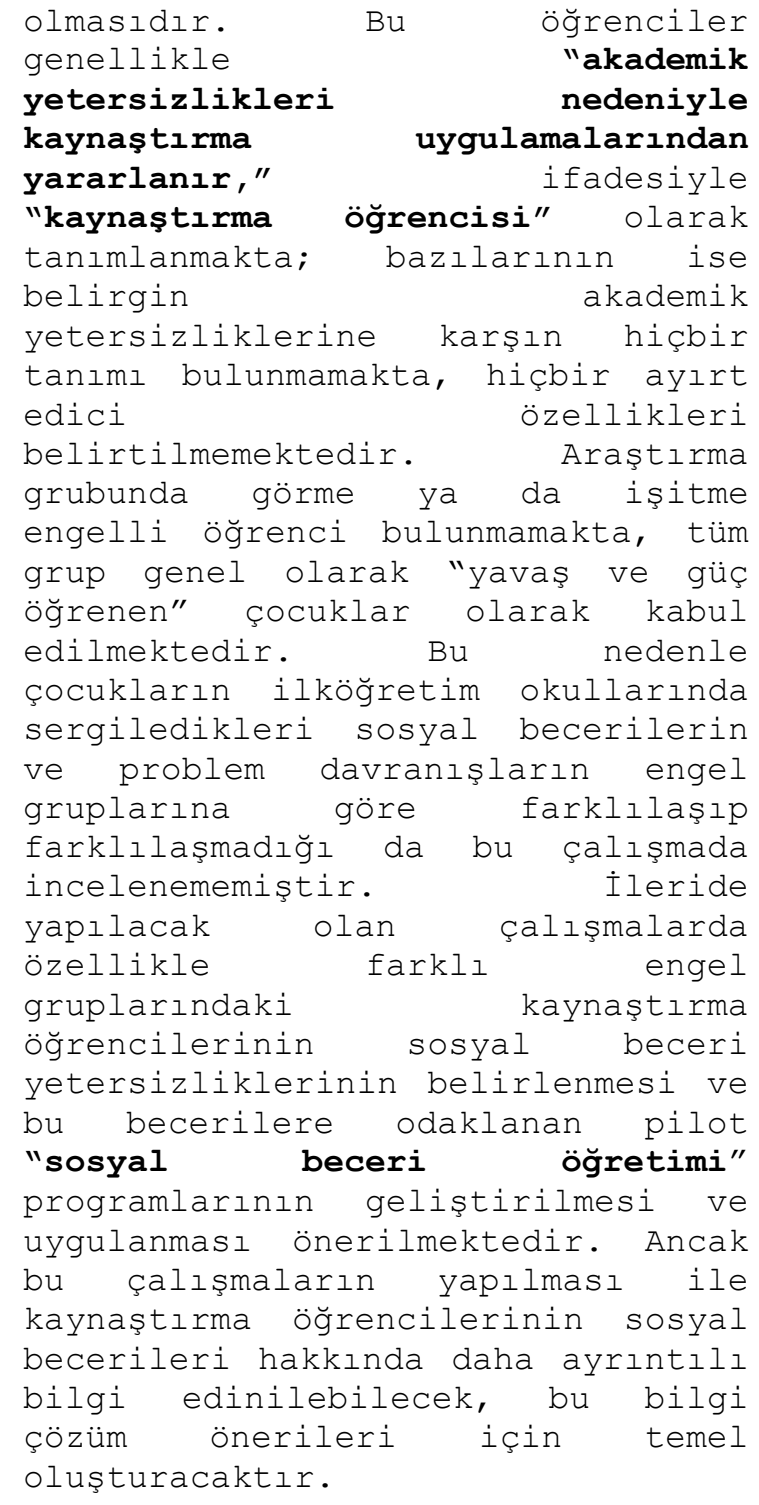




\section{KAYNAKLAR}

Achenbach, T. M., \& Edelbrock, C. (1986). Manual for the Teacher's Report Form and Teacher Version of the child Behavior Profile. Burlington: University of Vermont, Department of Psychiatry.

Akçamete, G., \& Ceber, H. (1999). Kaynaştırılmış sınıflardaki işitme engelli ve işiten öğrencilerin sosyometrik statülerinin karşılaştırmalı olarak incelenmesi. Özel Eğitim Dergisi, 2(3), 44-74.

Baysal, E. N. (1989). Okul öncesi dönemindeki Down sendromlu ve normal gelişim gösteren çocukların entegrasyonunda sosyal iletişim davranışlarının incelenmesi. Yayınlanmamış doktora tezi, Hacettepe Üniversitesi, Ankara.

Beckman, P. J., \& Kohl, F. L. (1987). Interaction of preschoolers with and without handicaps in integrated and segragated settings: A longitudinal study. Mental Retardation, 25, 5-11.

Chadsey-Rusch, J. (1992). Toward defining and measuring social skils in employment settings. American Journal on Mental Retardation, 96(4), 405-418.

Ciechalski, J. C., \& Schmidt, M. W. (1995). The effects of social skills training on students with exceptionalities. Elementary School Guidance \& Counseling, 29(3), 217-223.

Clegg, J.A., \& Standen, P.J. (1991). Friendship among adults who have developmental disabilities. American Journal on Mental Retardation, 95, 663667.

Çifci, İ. \& Cora-İnce, N. (2002). Zihinsel engelli öğrencilerin davranış problemlerinin öğretmen adayları tarafından belirlenmesi. XII. Ulusal Özel Eğitim Kongresi Bildiri Kitabı. Ankara: Ankara Üniversitesi Eğitim Bilimleri Fakültesi Yayınları, Yayın no: 193 .

Çiçekçi, A. (2000). 10-15 yaş grubundaki engelli bireyler ile engelli olmayan bireylerin davranış problemlerinin karşılaştırmalı olarak incelenmesi. Yayınlanmamış yüksek lisans tezi, Anadolu Üniversitesi, Eskişehir.

David, J., Elfenbein, J., Schum; R., \& Bentler, R. (1986). Effects of mild and moderate hearing impairments on language, educational and psychosocial behavior of children. Journal of Speech and Hearing Disorders, 51, 53-62.

Hunt, P., Atwell, M., Farron-Davis, F., \& Goetz, L. (1996). Creating socially supportive environments for fully included students who experinces multiple disabilities.Journal of the Association for Persons with Severe Handicaps, 21, 53-71.

Freund, L. S., \& Reiss A. (1991). Rating problem behaviors in outpatients with mental retardation: Use of the aberrant behavior checklist. Research in Developmental Disorders, 12, 435.

Green, S.B., Salkind, N.J., \& Akey, T.M. (1997). Using SPSS for Windows. New Jersey: Prentice Hall.

Gresham, F. M. (1983). Social skills assessment as a component of mainstreaming placement decisions. Exceptional Children, 49, 331-336.

Gresham, F. M. (1986). Conceptional and definitional issues in the assessment of children's social skills: Implications for classifications and training. Journal of Clinical Child Pyschology, 15(1), 3-15.

Gresham, F. M., \& Elliot, S. N. (1990). Social Skills Rating System. Circle Pines: American Guidance Services.

Gresham, F. M. (1997). Social competence and students with behavior disorders: Where we've been, where we are, and where we should go. Education and Treatment of Children, 20(3), 233-250.

Gresham, F. M., Sugai, G., \& Horner, R. H. (2001). Interpreting outcomes of social training for students with high incidence disabilities. Exceptional Children, 67(3),

Guralnick, M., \& Groom, J.M. (1987). The peer relations of mildly delayed and 
nonhandicapped preschool children in mainstreamed play groups. Child Development, 58, 1558-1572.

Guralnick, M. (1990). Social competence and early intervention. Journal of Early Intervention, 14, 3-14.

Kaner, S., \& Çiçekçi, A. (2000). Gözden Geçirilmiş Davranış Problemleri Kontrol Listesi'nin Türkçe'ye uyarlanması. Özel Eğitim Dergisi, 2(4), 23-34.

Kargın, T., Acarlar, F., \& Sucuoğlu, B. (2005). Öğretmen, yönetici ve anne babaların kaynaştırma uygulamalarına ilişkin görüşlerinin belirlenmesi. Özel Ĕ̆itim Dergisi, 4(2), 55-76.

Lane, K. L. (2004a). Teacher expectations of student behavior: Social skills necessary for success in elementary school classrooms. Journal of Special Education, Summer. Retrieved November 17, 2004, from http:// wWw. findarticles.com/p/articles/mi moHD F.

Lane, K. L. (2004b). Secondary teachers views on social competence: Skills essentials for success. Journal of Special Education, Fall. Retrieved March 21, 5005 from http:// www. findarticles.com/p/articles/mi moHD F.

Maag, J.W., \& Webber, J. (1995). Promoting children's social development in general education classrooms. Preventing School Failure, 39(3), 1320 .

Madden, N., \& Slavin, R. (1983) Mainstreaming students with mild handicaps: Academic and social outcomes. Review of Educational Research, 53, 519-659.

Marzano, R. J., \& Marzano, J. S. (2003). The key to classroom management. Educational Leadership, 61(1), 6-17.

Merrell, K.W., \& Gimpel, G. A. (1998). Social skills of children and adolescents. Conceptualization, assessment, treatment. London: Lawrence Earlbaum Associates Publishes.
Miller, M. J., Lane, K. L., \& Wehby, J. (2005). Social skills instruction for students with high incidence disabilities: A school based intervention to address acquisition deficits. Preventing School Failure, $49(2), \quad 27-39$.

O'Neill, R. E. (1997). Autism. In J.W. Wood \& A.A. Lazzari (Eds.), Exceeding the boundries: Understanding exceptional lives (424-461). Fort Worth: Harcourt \& Brace Co.

Poyraz-Tüy, S. (1999). 3-6 yaş arasındaki işitme engelli ve işiten çocukların sosyal beceri ve problem davranişları yönünden karşılaştırılması. Yayınlanmamış yüksek lisans tezi, Ankara Üniversitesi, Ankara.

Russell, A. T., \& Forness, S. R. (1985). Behavioral disturbance in mentally retarded children in TMR and EMR classrooms. American Journal of Mental Deficiency, 89(4), 338-344.

Sabornie, E. J., \& Beard, G. H. (1990). Teaching social skills to students with mild handicaps. Teaching Exceptional Children, 23(1), 35-38.

Sargent, L. R. (1991). Social skills for school and community: Systematic instruction for children and youth with cognitive delay. Washington, D.C.: The Division on Mental Retardation of the Council for Exceptional Children.

Semmel, M., \& Gao, X. (1992). Teacher perception of the classroom behaviors of nominated handicapped students in China. Journal of Special Education, $25,415-430$.

Silver, C. H., Elder, W. G., \& DeBolt, A. J. (1999). Social skills self-appraisal of children with arithmetic disabilities. Developmental Neuropsychology, 16(1), 117-127.

Snell, M. E., \& Janney, R. (2000). Teachers' guides to inclusive practices: Social relationships and peer support. Baltimore: Paul $\mathrm{H}$. Brookes Publishing Co. 
Sucuoğlu, B. (2003). Sorun Davranışlar Kontrol Listesi Türkçe Formu'nun psikometrik özelliklerinin incelenmesi. Türk Psikoloji Dergisi, 18(52), 77-91.

Şahbaz, Ü. (2004). Kaynaştırma sınıflarına devam eden zihin engelli öğrencilerin sosyal kabul düzeylerin belirlenmesi. 13. Ulusal Özel Eğitim Kongresi. Ankara: Kök Yayınevi.

Uysal, A. (1999). Zihinsel engelli ve normal ögrencilerin sosyal beceri düzeylerinin karşılaştırılması. 4. Ulusal Eğitim Bilimleri Kongresi'nde sunulmuş bildiri, Eskişehir.

Uysal, A. (2003). Kaynaştırma uygulaması yapan öğretmenlerin kaynaştırmaya ilişkin görüşleri. 13. Ulusal Özel Eğitim Kongresi. Ankara: Kök Yayınevi.

Vaughn, S., Elbaum, B. E., \& Schumm, J. S. (1996). The effects of inclusion on the social functioning of students with learning disabilities. Journal of Learning Disabilities, 29, 598-608.

Vostanis, P., Bickerton, W. L., Cumella, S., Chung M. C., Winchester, C., \& Doran, J. (1996). Mother and teacher ratings of maladaptive behavior in children with special needs. European Journal of Special Needs, 11(1), 117124 .

Zirpoli, J. T., \& Melloy, K. J. (1997). Behavior management: Application for teachers. Ohio: Merrill prentice Hall. 